\title{
On Lithocodium Elliott (Calcareous algae); its paleobiological and stratigraphical significance
}

\author{
F. T. BANNER, E. M. FINCH \& M. D. SIMMONS \\ Exploration Technology Branch, BP Research Centre, Chertsey Road, \\ Sunbury-on-Thames TW16 7LN
}

\begin{abstract}
Lithocodium aggregatum Elliott (with its synonyms, Bacinella irregularis Radoičić and Pseudolithocodium carpaticum Mišík), Radoicicinellopsis sterni (Radoičić) and Bacinellacodium calcareus Dragastan are referred to the new subfamily Lithocodioidea of the family Codiaceae (marine, chlorophycean, calcareous algae). The significance which has been ascribed to these taxa by past authors is assessed. Radoicicinellopsis is proposed as a new genus. Lithocodium is redescribed and its diagnosis is emended. The importance of this alga in palaeoenvironmental interpretation and fossil hydrocarbon accumulation is noted.
\end{abstract}

\section{INTRODUCTION}

Lithocodium aggregatum was first described as a new genus and new species by Elliott $(1956,1957)$ using specimens obtained in thin section from "Lower Cretaceous" limestones of the Rumaila No. 4 well, Iraq. The taxon, which was firmly referred to the codiacean algae, was subsequently recorded to occur abundantly in the top of the Iraqi Ratawi Formation with Pseudocyclammina lituus (Dunnington et al., 1959), of probable Hauterivian age, and at least as high stratigraphically as the Albian in that country (Elliott, 1963). L. aggregatum was also reliably recorded in the Early Cretaceous limestones of Iran (Kalantari, 1986, text-fig. 85.1) from the Lekhwair Formation (broadly equivalent to the Ratawi Formation) of Oman (Simmons \& Hart, 1987) and abundantly in the succeeding Kharaib and Shuaiba Formations (Barremian - Aptian) of the southern Arabian Gulf (Alsharhan, 1985; Alsharhan \& Nairn, 1986; Simmons \& Hart, 1987). This species has also been found in the upper Aptian of Lebanon (Basson \& Edgell, 1971), and in limestones as old as Berriasian - Valanginian in Sharjah, U. A. E. (Connally \& Scott, 1985). Eastwards, L. aggregatum has been recorded from the Cenomanian - Turonian of central Afghanistan (Kaever, 1965), from the late Aptian of north India (Cherchi et al., 1984) and from the early Cretaceous of China (Mu Xi-nan, 1986). The species is also known westwards, from southern Europe (Urgonian of Bulgaria, Chrischev \& Bakalova, 1974; early Cretaceous of the Italian central Apennines, Praturlon, 1964; Aptian of southern Italy, Luperto Sinni, 1979; Late Jurassic to Cenomanian in southern French Aquitaine, Bouroullec \& Deloffre, 1968; Valanginian - Gargasian of the French eastern Pyrenees, Jaffrezo, 1975; Oxfordian - Portlandian of Portugal, Ramalho, 1971), but it does not yet appear to have been found in northern Europe or, with certainty in North Africa or America; it has been recorded, but not illustrated, from the early Cretaceous of Cúba, Texas and the Blake Escarpment (Johnson, 1968, 1969).

Quite independently of the proposal of Lithocodium, Radoičić (1959) had published, also as a new genus and new species, Bacinella irregularis, based upon thinsections of "algae incertae sedis" in "BarremianAptian" limestones of Bosnia and Serbia, in the Yugoslav Dinarides. These findings were confirmed (Radocičić, 1960) and B. irregularis was recorded from many Early Cretaceous limestones of southern Europe (e.g, , the Valanginian - Aptian of S.W. Italy, Sartoni \& Crescenti, 1962; early to late Aptian limestones of S. Italy, Chiocchini \& Mancinelli, 1977; Valanginian to Bedoulian linestones in Provence, Masse, 1976) as well as in rocks of about the same age from more eastern localities (the Shuaiba Formation, Aptian, of Oman, Hughes Clarke, 1988; the Valanginian to Hauterivian limestones, with Pseudocyclammina lituus, in Iran, Sampo, 1969; early Cretaceous limestones in China, $\mathrm{Mu}$ Xi-nan, 1986). Occurrence in limestones as old as Late Jurassic have also been recorded from southern Europe (Portugal, "Upper Oxfordian/Kimmeridgian" to Valanginian, Ramalho, 1971; the French eastern Pyrenees, late Jurassic - Late Urgonian, Jaffrezo, 1975; the late Jurassic to Cenomanian of Aquitaine, Bouroullec \& Deloffre, 1968; "Portlandian" of central Ialy, Barattolo \& Pugliesi, 1987; Tithonian to Barremian near Bucarest in Roumania, Dragastan 1966; unspecified Upper Jurassic limestones of mainland Greece, Zambetakis-Lekkas \& Karotsieris, 1986). Bacinella has also been recorded from the Triassic (Samuel et al., 1972, p. 129; Borza, 1975, pl. 4) but these records are yet to be confirmed.

Like Lithocodium, B. irregularis seems not to have 
been recorded with any reliability from northern Europe, Africa or America. The two taxa have remarkably similar confirmed recorded ranges; both are certainly known in the late Jurassic - middle Cretaceous limestones of Tethys, in the Portugal to China area. Even if other species, originally assigned to these genera, are included, the main pattern of distributions is not significantly changed; Endo (1961) reported $L$. japonicum and $L$. morikawai, both new species, from Upper Jurassic limestones of Japan (Johnson, 1964), and Radoičić (1972) described as new B.? sterni from Cenomanian limestone in Yugoslavia (Conrad et al., 1977).

The similarity of stratigraphic range and palaeogeographical distribution is paralleled by that of the morphology of the type specimens of the principal taxa concerned. Elliott (1956) illustrated microphotographs of three specimens of $L$. aggregatum, which represented the holotype (1956, pl. 1, fig. 5) and two paratypes (loc. cit., figs. 2 and 4) from the same subsurface sample. Together, they clearly showed the character believed to typify Lithocodium - an encrusting or nodose growth mode in a codiacean with a subdermal skeletal structure similar to that of regularly segmented genera (like Halimeda). One of the paratypes (loc. cit., fig. 4) particularly well showed that the inner, irregularly oriented but coarse filaments could be surrounded by an outer layer of much finer, subradial filaments, and that, in both layers, the filaments could be separated by calcified tissues as thick, or even thicker than, the filaments themselves. This paratype is very similar indeed to the holotype of Bacinella irregularis Radoičić.

When Radoičić (1959) first described B. irregularis, she published photomicrographs of two specimens from different localities, the holotype (1959, pl. 3, fig. 1) and one paratype (loc. cit., fig. 2). Although Radoičić noted that the "subdermal structure" (that is, the outer layer filamentous arrangement) could be "similar to that one of the species Lithocodium aggregatum Elliott" (Radoičić, 1959, p. 92), she did not clearly attempt to distinguish between them. The holotype of $B$. irregularis is morphologically very similar indeed to L. aggregatum, as noted above, and is distinguishable only by the more frequent occurrence in the former of thin walls separating the adjacent cells of particular filaments. This difference is one of degree; thin walls separate adjacent cells while thickly calcitised tissues separate adjacent filaments in both specimens, in both the outer and the inner layers of the thalli. A more clearly recognisable difference between the taxa appears to be shown by the morphology of the illustrated paratype of $B$. irregularis (Radoičić, 1959, pl. 3, fig. 2). In this specimen, only the inner layer of the thallus is seen (no cortex is visible), and all the filaments are of the coarser kind and are very randomly arranged, with no clear directions of growth; their cells are divided only by thinly calcitised walls, and walls of equally thin calcification may separate adjacent filaments. It is this "vacuolated" and apparently poorly organised structure, regardless of the precise morphology of the holotype, which has been taken by many authors to typify Bacinella. This is in spite of the fact that "systematic distinction based essentially on the degree of calcification appears to be wrong" (Bassoullet et al., 1977) in any member of the Chlorophyta.

Variation in the degree of calcification was even used by Mišík (1979) for the distinction of his new genus Pseudolithocodium (typified, monotypically, by $P$. carpaticum Mišík n.sp.) which was clearly corticate, like Lithocodium, but in which "the tubes of [the] cortical layer are densely packed, not submerged in micrite" (Mišík, 1979, p. 709). In other words, the thickness of the calcified tissues between the filaments of the cortex of "Pseudolithocodium" is no greater than it was between the filaments in the subcortical parts of the paratype Bacinella irregularis. It is clear, from these specimens alone, that the degree of calcification varied in forms with and without a cortex, and that it would seem to be unwise to use an observed degree as the basis for a taxonomic distinction. Such taxa would be difficult to distinguish in many other fossil assemblages.

Although some authors (e.g., Alsharhan, 1985; Luperto Sinni, 1979; Poignant, 1968; Simmons \& Hart, 1987) have concluded that Lithocodium and Bacinella are synonymous genera of the Codiaceae, others (e.g., Barattolo \& Pugliese, 1987; Bouroullec \& Deloffre, 1968; Elliott, 1963; Jaffrezo, 1975; Ramalho, 1979) have considered them as separable, probably distinct genera of that same suprageneric group. Some (e.g., Chrischev \& Bakalova, 1974; Johnson, 1968, 1969) have been willing to refer Lithocodium to the Codiaceae, but have been unhappy to consider Bacinella as anything but "algae incertae sedis"; Radoičić (1959) is unclear but probably belonged to this group of workers. Opposed to this view is that of those who believe that Lithocodium and Bacinella were of organic origin, but not from the Codiaceae (Segonzac \& Marin, 1972). Previous systematic assignations of Lithocodium-Bacinella have encompassed both the green and the red algae. Both the Codiaceae and Dasycladaceae, the marine families of the Chlorophyta, are skeletally aragonitic, and only the Corallinaceae of the Rhodophyta are calcitic (e.g. Wray, 1977). No published photomicrograph, or unpublished but studied specimens, give any indication that $L$. aggregatum or $B$. irregularis were anything but primarily calcitic. This is discussed further in this paper. The taxa have also been considered to belong to zoological phyla, and have been referred to orders as diverse as the stromatoporoids and the foraminifera (see, e.g., Marin et al., 1985). Masse (1976) has suggested that these microfos- 
sils were of botanical but multiple origin, comparable to the algal symbioses seen in terrestrial lichens.

Maurin et al. (1985) and Camoin \& Maurin (1988), basing their decisions on material from the Upper Cretaceous of Tunisia, the Lower Cretaceous of Sicily and the Middle East, and the Upper Jurassic of Sumatra, claimed that the origin was universally microbial; they extended the stratigraphic significance of "bacinellid-textures" to include everything from Precambrian to Recent, but admitted that "the debate is not closed". There can be no doubt that the microstructures commonly known as Lithocodium and Bacinella are common in micritic, calcareous, apparently well oxygenated, marine sediments of Mesozoic age in Tethys; if their origin is merely microbial, why are they confined to these Tethyan, Mesozoic carbonates? Why do not identical microstructures occur equally commonly in argillites, in the Americas, and in sediments of Tertiary and even Quaternary-Recent age? Again, if their origin is merely microbial, why is there such a narrow size-limitation on the "vesicles" of both Lithocodium and Bacinella, when both, it is presumed, would be merely lithified bubbles of (calcareous!) mud following microbial gasgeneration? The "bacinellid-texture" developed in stromatolites may even there have an algal origin (Wright \& Wright, 1985); true Lithocodium-Bacinella specimens are, as show below, nodular-encrusting and are not at all stromatolitic (or mud-mound-like) even in gross growth-plan. As for the bacterial genesis of the calcium carbonate itself, nothing can be proved: as would be expected, all the specimens of the Mesozoic microfossils that we have studied have undergone recrystallisation to some degree (not excluding obvious dolomitisation!) and this may obscure resemblance to any of the biogeochemically produced carbonate grains shown in her 38 plates by Castanier (1987); grains which resemble lithified (or SEM coated?) bacteria may, of course, be found, but bacteria are present on all organisms, living and dead. The aseptic alga would be unique.

In this paper, we attempt to demonstrate the identity of Lithocodium aggregatum, Pseudolithocodium carpaticum and Bacinella irregularis, the place these microfossils have within the Codiaceae, their signifcance in the interpretation of palaeovenvironments, their role in producing high intraparticle porosity, and, therefore, their importance as primary producers of porous linestone petroleum reservoirs in the Middle East.

\section{MATERIALS AND METHODS}

The problem was highlighted by the need to study the Early Cretaceous sequences (the Shuaiba, Kharaib, Lekhwair and Habshan Formations) retrieved during field geology in Oman (Simmons \& Hart, 1987) and during oil-well drilling in the United Arab Emirates (particularly in offshore and onshore Abu Dhabi). Core-slab successions from eleven selected wells were studied macroscopically in the laboratories of ADNOC. In total, the work has provided many thousands of field, core and cuttings samples of limestones which have been routinely examined in thin section for their entire assemblages of fossil macrofauna and microflora. Many of the sections of well core were routinely stained with Alizarin Red-S, and impregnated with resin, to identify dolomite and ferroan calcite and to enable quantification of crystallography and porosity.

Additional material, similarly studied, was obtained from the southern Apennines, Italy; these limestones displayed well-preserved sections of LithocodiumBacinella but the specimens were solidly infilled with secondary, sparitic calcite. Most of the specimens available from the Middle East lacked such solid infilling, and some (especially from the Lekhwair formation) seemed to possess a total lack of secondary infilling; these, especially, were studied under S. E. M.

\section{THE IDENTITY OF LITHOCODIUM AND BACINELLA}

As noted above, the holotype and paratype thinsections of Lithocodium aggregatum (Elliott, 1956) undoubtedly refer to the same species and they are not to be separated from the holotype thin-section of Bacinella irregularis (Radoičić, 1959). This was emphasised and most clearly shown by Segonzac \& Marin (1972), who illustrated every conceivable morphological intermediate between the holotypes of the two taxa, using only Aptian limestone specimens from north-east Spain. Such morphological intermediates are also illustrated here (Plates 1-5). There can be no doubt that Lithocodium aggregatum Elliott is the senior synonym for all such forms. Similarly, L. aggregatum, for the reasons noted above, must be regarded as the senior synonym of Pseudolithocodium carpaticum Mišík.

Ramalho (1971, pl. 29, fig. 1) has illustrated a remarkably well preserved nodule formed by Lithocodium (reproduced here as fig. 1), in which the pattern of growth of the alga may be noted. This nodule shows no erosion or abrasion from any post-mortem transportation; it was probably buried virtually in situ in the calcite-mud which now forms the micritic matrix of its rock. The posture and structure of the nodule shows that it has nothing in common with the layered, unstructured stromatolites of gaseous, microbial origin (c.f. Maurin et al., 1985). A smaller nodule of Rivularia (a) forms the base upon which the Lithocodium grows (organic nodules typically form such bases - e.g., sponge skeletons as shown by Cherchi et al., 1984, pl. 1, or microgastropods, as on Pl. 4, fig. 4 - but they provide substrates for initial algal colonisation, as they 

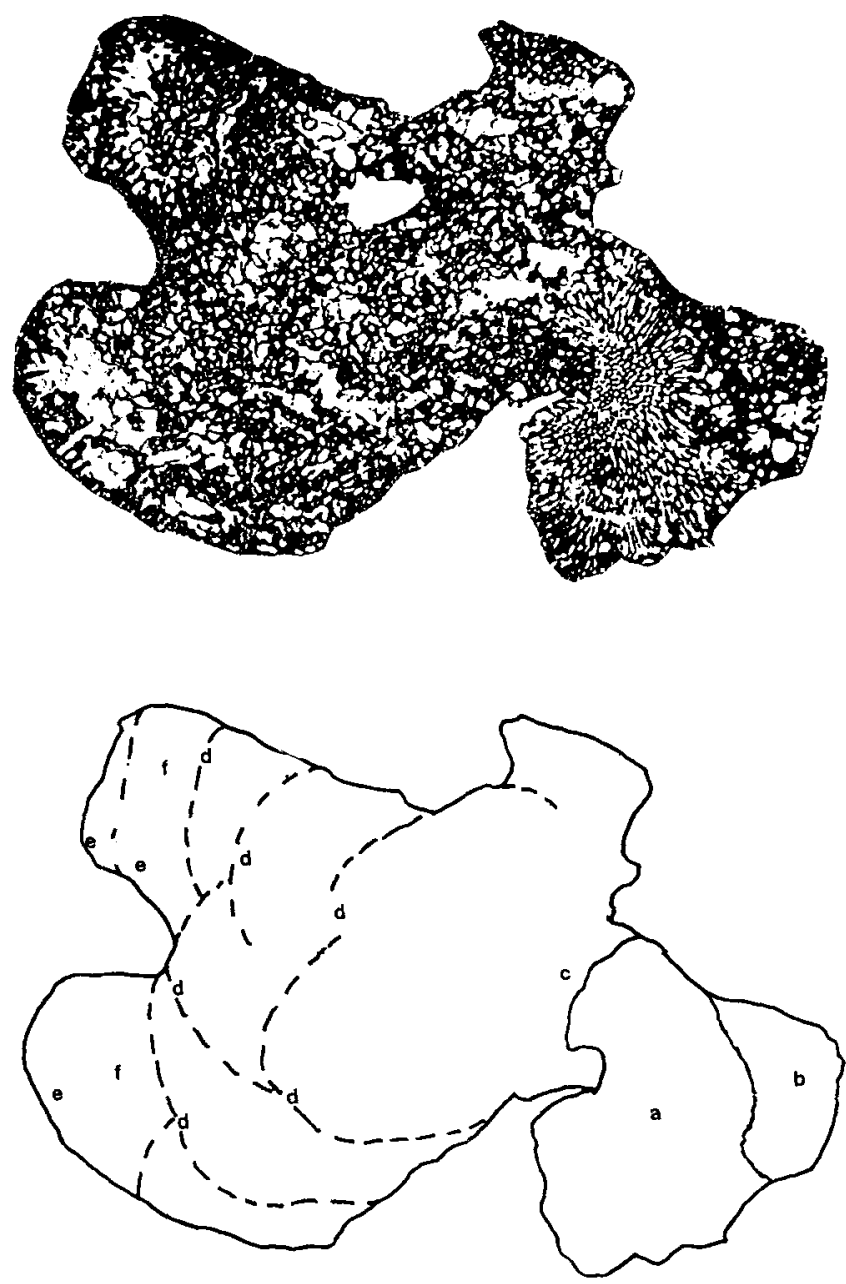

Fig. 1. A well preserved nodule of Lithocodium encrusting Rivularia, $\times 5$ (From Ramalho, 1971). See text for further explanation.

are always too small to have provided decaying bases for adequate microbial flatulence of the kind favoured by Maurin et al.1985). The Rivularia nodule is partly covered $(b)$ by thick-walled cortical and near-cortical Lithocodium skeleton and partly (c) by thin-walled medullary structures. The latter show at least four successive layers of cortical development $(d)$ now embedded in the skeleton of the thallus. The lastformed cortical structures $(e)$ are thickest-walled, but lie directly on top of poorly calcified, "vacuolated" medulla $(f)$. Laterally to the main thallus growth direction, no recognisable cortex structures are apparent.

From this and similar specimens, problems of identity are isolated: (1) Although some specimens have every appearance of possessing a codiacean cortex of fine, subradial filaments, such specimens may also appear to lack a siphonate, filamentous medulla. As pointed out by Segonzac \& Martin (1972, p. 334) "Lithocodium présente une aberration apparente de structure, avec une base cloisonnée et un sommet siphoné. Il ne rentre dans aucune catégorie actuelle ou fossile." This is not typically Codiacean, if the preserved skeletal structure is a true reflection of the original tissues. (2) Other specimens, like the paratype of Bacinella irregularis, appear to lack any cortical skeletal structure and merely consist of irrgularly arranged, coarse (but with little apparent consistency of size), "medullary" siphons or filaments, which may be septate. This appears to be an opposite condition from that noted as (1), above, but would be easily derived from sections of specimens cut across the thallus, at right angles to the direction of thallus growth, where the cortical, terminal structure is not yet developed.

Such apparent contradictions are easily explained not only by the specimen described above but by the characteristic property of the Codiaceae to calcify secondarily, after the complete growth of soft tissue, and then perhaps to calcify only partially. Partial calcification may leave some tissue without a calcareous skeleton. This is commonest in those Codiacea where then thallus is composed of erect tufts (e.g., Halimeda, Boueina, etc.): as Johnson (1969, p. 35) so clearly put it, "calcification . . . begins at, or just inside, the outer margin and works inward. Older segments may be completely calcified, but many specimens show only partial clacification with the central structure not preserved."

We believe that Lithocodium-Bacinella answers the following description:

(a) It grew as an essentially encrusting codiacean, and was not erect and tufted,

(b) It developed a nodular thallus in which only the terminal zone of growth developed cortical structures.

(c) It may have been only partially calcified and that calcification began internally; consequently, the medulla is always calcified, but the cortex may be fully calcified (P1. 1, figs. 1-4 and Pl. 3, fig. 1, as

\section{Explanation of Plate 1 \\ Lithocodium aggregatum Elliott}

Fig. 1. Photomicrograph $(\times 16)$, Shuaiba Formation, subsurface Abu Dhabi.

Fig. 2. Photomicrograph $(\times 40)$, Shuaiba Formation, subsurface Abu Dhabi.

Fig. 3. Photomicrograph $(\times 40)$, Shuaiba Formation, subsurface Abu Dhabi.

Fig. 4. Photomicrograph $(\times 13)$, Shuaiba Formation, Wadi Bani Kharus, Oman Mountains. 

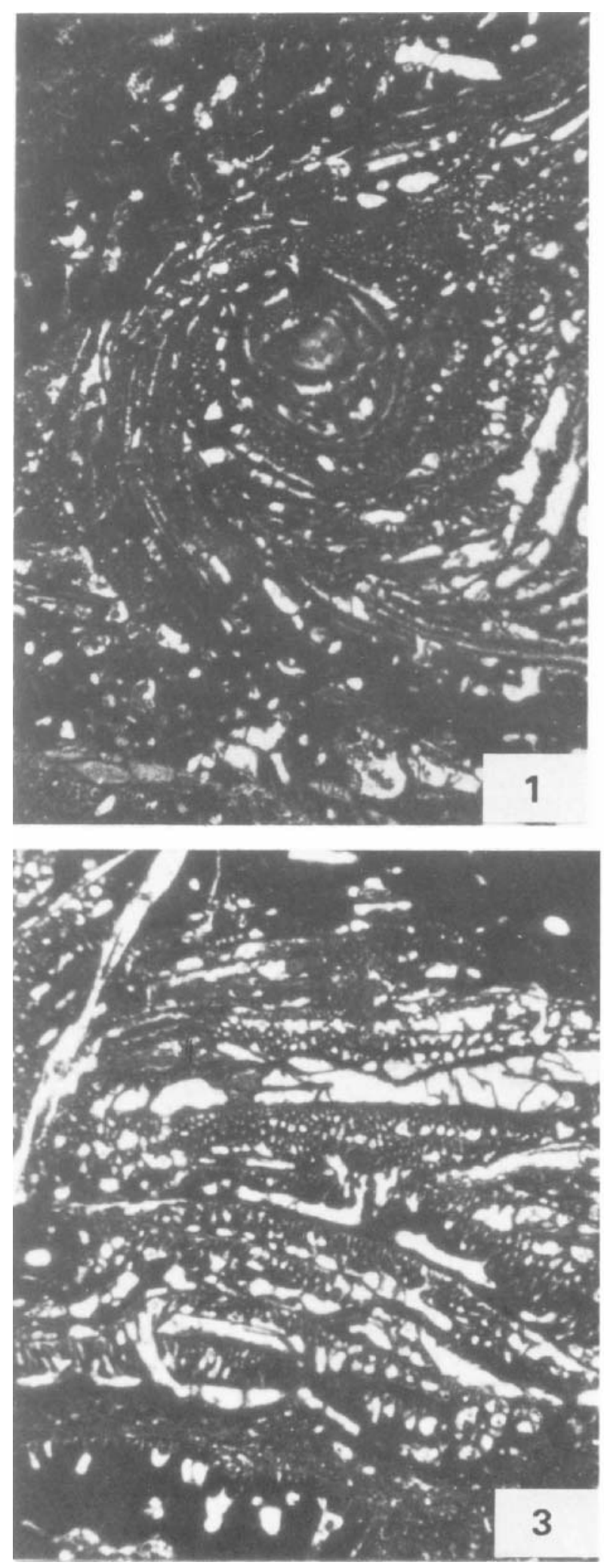
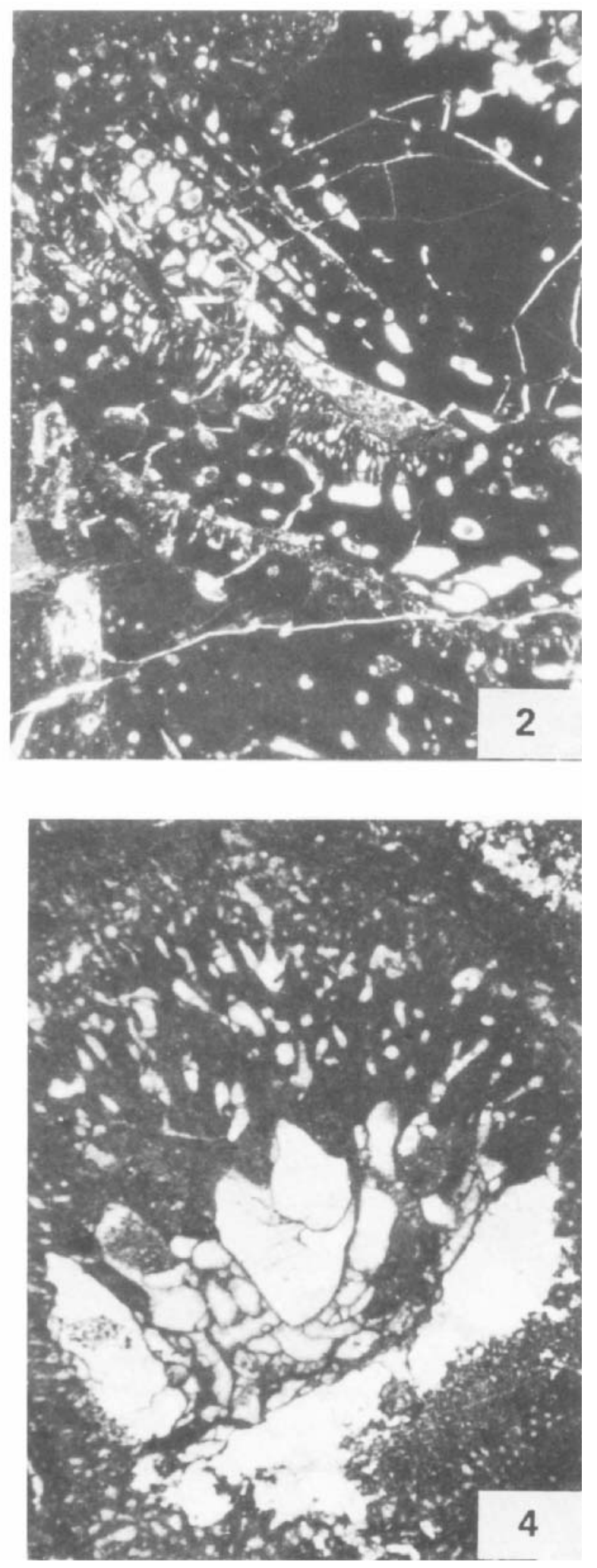
in the paratype of $L$. aggregatum and the holotype of $B$. irregularis), or only partly calcified (as shown by Praturlon, 1964, fig. 28).

(d) Even where the medullary or cortical calcification appears to have been complete (in the sense that all tissues possessed a skeleton), the degree of calcification was variable, in that in some areas (or specimens) the calcified layers were relatively thin, but in other areas (or specimens) they were relatively thick.

(e) Thinly calcified walls, in particular, may have been skeletally discontinuous (e.g., Pl. 4. fig. 2). The absence of a skeletal wall does not mean that the living alga also lacked a wall of uncalcified tissue in that place; the absence of such skeletal walls gives the visual impression that many filamentous spaces are much larger than the filaments which occupied them, but it should not be interpreted to mean that the filaments, themselves, were so large.

We believe that all of the above apply not only to the Late Jurassic - Albian species Lithocodium aggregatum Elliott (and, of course, to its synonym Bacinella irregularis Radoičić) but also to the Jurassic synonyms called L. morikawai Endo and L. japonicum Endo. "Bacinella?" sterni Radoičić (as figured by Radoičić, 1972) followed the same pattern of growth and calcification in the Cenomanian, and differed from true Lithocodium only in the great reduction (almost to terminal absence) of the cortex. We distinguish, below, this species under a separate generic name (Radoicicinellopsis nov.) but in the same new subfamily, Lithocodioidea; we cannot agree with Masse (1979) in the transfer of this species to the Porostromata. The opposite morphological trend is displayed by the Tithonian - Aptian taxon with a variably calcified medulla but a heavily calcified cortex, distinguished as Bacinellacodium calcareus by Dragastan (1985); the principal difference from Lithocodium, that in Bacinellacodium the cortical filaments are distinctly thinner, longer and more parallel, is essentially a difference of degree, not of kind. The medulla is essentially the same in both genera, but may be very weakly calcified in Bacinellacodium. In the latter genus, the overall structure is distinctly Codiacean, with strong medulla - cortex differentiation. It confirms our allocation of Lithocodium itself to the family Codiaceae. Between these genera, we are disting- uishing not just degrees of calcification of components of the thallus, but the extent of primary development of the cortex itself; thick and solely terminal in Bacinellacodium, much reduced and repetitious in Lithocodium, but reduced even to a non-filamentous state in Radoicicinellopsis. This is not to be confused with the recognition of different degrees of calcification in different specimens of Lithocodium, where the degree of cortical development is essentially always the same. All of these genera are now referred (below) to the same, new subfamily, Lithocodioidea.

Of course, all of the Codiaceae can be readily distinguished from the members of the family Rivulariaceae Rabenhorst 1865, of the division Cyanophyta, as the latter have no medulla/cortex differentiation at all but merely possess regularly diverging filaments which are orientated subparallel to the long axis of the thallus (e.g., as in Rivularia (Roth) Agardh itself, which, according to Dragastan (1985), is a senior synonym of the commonly recorded genus Cayeuxia Frollo).

All these codiacean taxa appear to constitute a recognisably distinct group of Codiaceae, of common Late Jurassic - Cretaceous stratigraphic Tethyan range, and they often occur in association. Consequently, it is appropriate to recommend that fossils of the family Codiaceae be considered to comprise the following subfamilies of the Chlorophyta (the names following the standards outline by Jeffrey, 1973; Wray, 1977; Voss et al., 1983, articles 16-19).

\section{SYTEMATIC DESCRIPTIONS}

Class Chlorophyceae Kuetzing, 1843

Order Siphonales Wille, 1884

Family Codiaceae (Trevisan) Zanardini, 1843 Subfamilies:

(1) Halimedoidea nov. subfam.: thallus of erect tufts, regularly segmented; typically with filaments differentiated into an inner medulla and continuous outer cortex; typically with calcification of tissues between filaments, initially at or near the outer margin of the cortex; the medulla may be calcified, in whole or in part, or it may remain uncalcified; the calcareous skeleton is primarily aragonite; includes Halimeda, Boueina, Arabicodium, Carpathicodium, etc.

(2) Lithocodioidea nov. subfam.: thallus is encrusting, initially at least, and the fully-grown thallus may be nodose to subcylindrical in form; it is initially calcified at earliest tissue growth stages, but later it may lack

\section{Explanation of Plate 2 \\ Lithocodium aggregatum Elliott}

Fig. 1. Scanning electron micrograph $(\times 50)$, Shuaiba Formation, subsurface Abu Dhabi.

Fig. 2. Scanning electron micrograph $(\times 140)$, Shuaiba Formation, subsurface Abu Dhabi.

Fig. 3. Scanning electron micrograph $(\times 100)$, Shuaiba Formation, subsurface Abu Dhabi.

Fig. 4. Scanning electron micrograph $(\times 80)$, Shuaiba Formation, subsurface Abu Dhabi. 

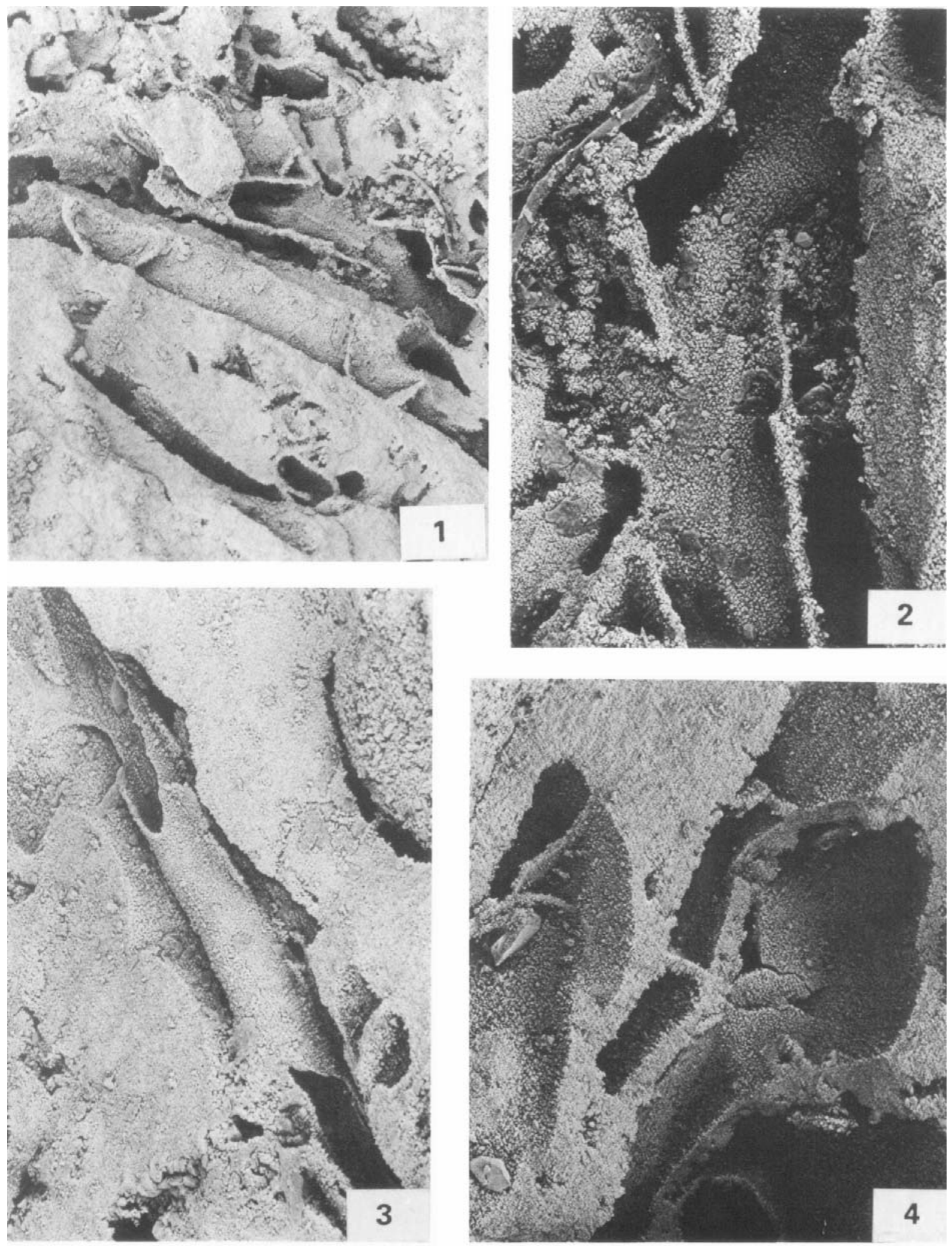
uniformity of the extent of calcification and may remain uncalcified in parts of the thallus; filaments are differentiated into those of an internal medulla and terminally the thallus has an external, usually filamentous cortex of increased calcification; the calcareous skeleton is probably primarily calcite; includes Lithocodium Elliott, Bacinellacodium Dragastan and Radoicicinellopsis nov.

Subfamily Lithocodioidea nov. Lithocodium Elliott, 1956, emend.

Lithocodium Elliott, 1956, p. 331

Bacinella Radoičić, 1959 , p. 89

Pseudolithocodium Mišík, 1979, p. 709

Descriptive diagnosis. A Codiacean genus of the subfamily Lithocodioidea (as defined above); initially encrusting, but the thallus may in later growth become subconical, subcylindrical or nodose in shape; the subdermal tubular filaments of the medulla are irregularly arranged, and encrust each other in various directions which are dominantly subparallel to each other and are broadly oblique to, or nearly at rightangles to, the long axis of the encrusting or nodular thallus; the subdermal filaments may bifurcate or trifurcate or variously ramify, and broaden before and during ramification, and are consequently of variable diameter; subdermal filaments are irregularly septate; in the area of terminal growth, the filaments narrow, become subparallel to the long-axis of growth of the previously-formed encrustation or nodule (i.e., they become subperpendicular to the planes of the subdermal filaments) and become heavily encrusted with microgranules of calcium carbonate to form a relatively heavily calcified cortex; in the cortex, the relatively narrow tubular filaments also bifurcate, trifurcate or variously ramify, but they diminish in diameter as they do so, so that the outermost cortical filaments (which have undergone the most ramifications) are the narrowest; the cortical filaments are terminated by a continuous thin sheet of calcium carbonate and are not open to the exterior, but this terminal sheet may be followed by resumed (originally lateral, then supraterminal) growth of subdermal filaments which are followed by another cortical development.

Remarks: Lithocodium differs from Bacinellacodium Dragastan in possessing distinctly shorter and broader cortical filments, and the walls of the subdermal filaments of the medulla are more strongly and continuously calcified; the medulla of Bacinellacodium is much reduced. In Lithocodium the cortex is relatively reduced, and is present typically only at the terminal growth-stage area of the thallus. Radoicicinellopsis nov. differs in its much more greatly reduced cortex (which may, in fact, be nonfilamentous even in terminal growth stages); the medulla of that genus is very much enlarged.

\section{Lithocodium aggregatum Elliott emend.} (Plates 1-5)

1956 Lithocodium aggregatum Elliott: 331, pl. 1, figs. 2, 4-5.

1959 Bacinella irregularis Radoičić: 89, 92, pl. 3, figs.1-2.

1979 Pseudolithocodium carpaticum Mišík: 709, pl. 2, figs. 2-8.

Diagnosis. A species of the genus Lithocodium as defined above, in which the cortex is regularly formed and possesses two or more (usually three or more) phases of branching and diminution in size of the cortical filaments. The cortical filaments are circular or subcircular in cross-section, but those of the medulla are of irregular cross-section shape. The thalli are 1 to $5 \mathrm{~cm}$ thick.

Remarks. This genus may subjectively be monotypic. As noted by Johnson (1969, p. 38), "L. regularis" Johnson, 1968, was a complete error: "unfortunately the author identified this as an alga by mistake. It is a foraminifer." The Jurassic taxa L. japonicum Endo and L. morikawai Endo, 1961, do not seem to be separable at species level from the range of variation observed in Early Cretaceous specimens of L. aggregatum.

The thallus of $L$. aggregatum may consist of a few, broad medullar-cortex growths (as depicted in Textfigure 1, derived from Ramalho, 1971) and this morphologically grades into forms where there are many, narrow but otherwise similar growths (Pl. 1, fig. 1). Even in such thalli, the medullary filaments are septate (Pl. 1, fig. 2; Pl. 2, figs. 1, 4), and they are distinctly tubular (Pl. 2, fig. 3). They ramify diversely with marked broadening of their diameters (Pl. 1, figs. 3 , 4; also Pl. 2, fig. 2, where one tube quadrifurcates, the two outer ramifications rapidly bending into the specimen, one of the two inner ramifications later doing the same, and the remaining branch continuing

\section{Explanation of Plate 3 \\ Lithocodium aggregatum Elliott}

Fig. 1. Scanning electron micrograph, back-scattered electrons $(\times 25)$, Shuaiba Formation, subsurface Abu Dhabi. Fig. 2. Scanning electron micrograph, back-scattered electrons $(\times 140)$, Shuaiba Formation, subsurface Abu Dhabi. Fig. 3. Scanning electron micrograph, back-scattered electrons $(\times 75)$, Shuaiba Formation, subsurface Abu Dhabi. Fig. 4. Scanning electron micrograph, back-scattered electrons $(\times 32)$, Shuaiba Formation, subsurface Abu Dhabi. 

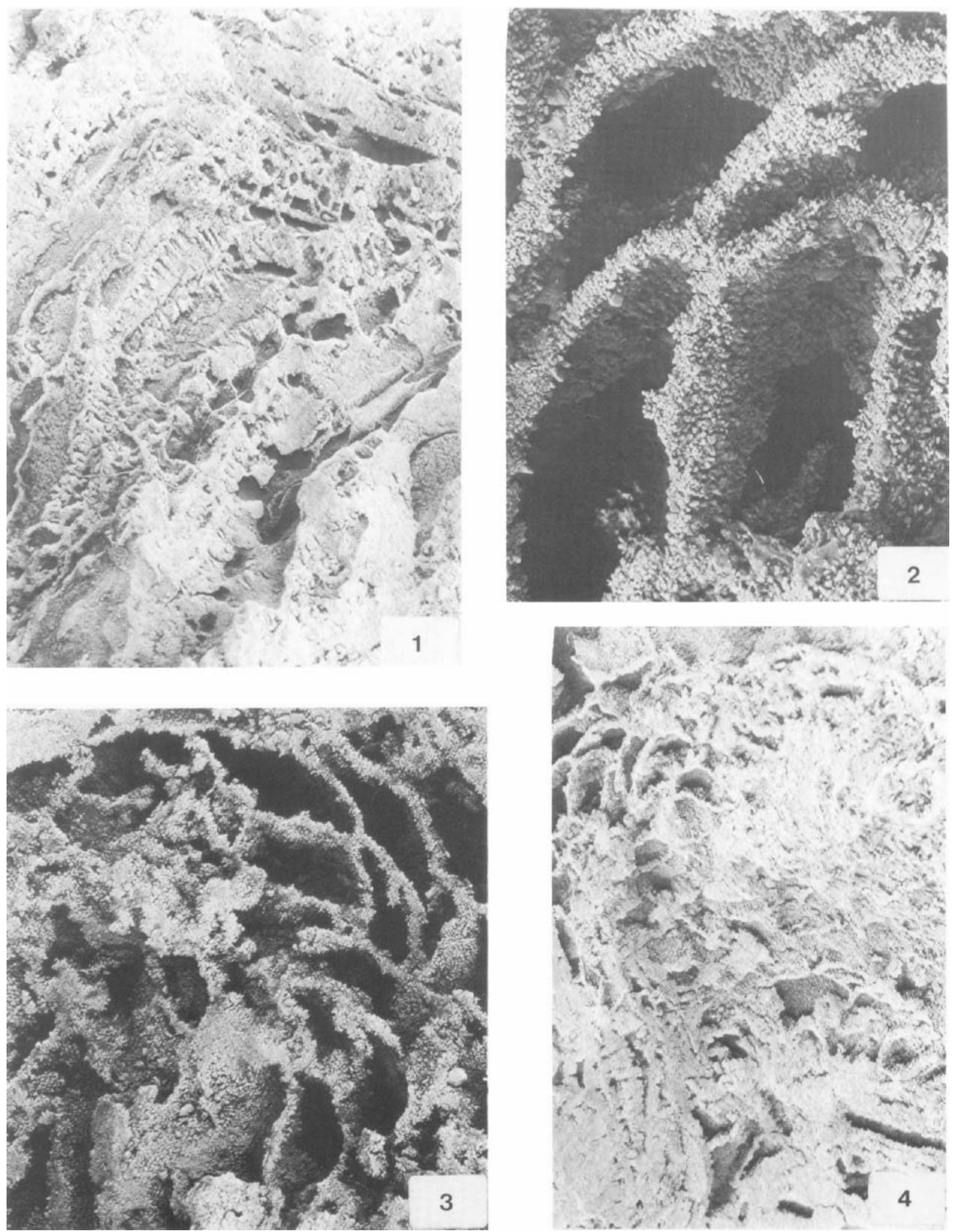
on a path in the same plane as the original tube), but this apparent broadening may also result from incomplete calcification of the walls of the medullar filaments (Pl. 2, fig. 4). These medullary, subdermal filaments are stacked upon each other, often encrusting earlierformed medullae in subparallel planes (PI. 3, figs. $2-4)$. The cortical filaments are heavily calcified and they are distinctly narrower than the previously formed, subdermal filaments (P1. 1, figs. 1-4; Pl. 3, fig. 1) but they may be seen to branch even in thin-section (Pl. 1, fig. 4). When it is cut obliquely, the complete, nodular thallus is usually seen, in random thin-section of its host limestone, to contain a subdermal (or, at least, initially formed) mass of broad, thinly-walled and relatively weakly calcified medullary filaments, and dermal, cortical filments which are distinctively heavily calcified, more clearly subparallel in direction, and which diminish in diameter towards the exterior of the thallus; such a section is characteristic of both the genus and its type species (Pl. 4, fig. 1).

The growth of the medullary filaments begins upon a substratum which is often biogenic (Rivularia sp., fig. 1 ; gastropod, Pl. 4, fig. 4) and which is soon encased in these filaments (Pl. 1, fig. 1; $\mathrm{Pl}$. 4, fig. 4). Other biogenic, skeletal fragments may be similarly encapsulated during the growth of the medulla; examples include miliolid and textulariid foraminiferan tests (Pl. 4, fig. 2) and other calcareous algae (Pl. 4, fig. 3, shows Thaumatoporella parvovesiculifera (Raineri) (= Polygonella incrustata Elliott) which now lies parallel to the previously formed subdermal filaments, seen lower right of the photograph, but which is encased by subsequently formed, but similar filaments on the other side). Where relatively large biogenic skeletal fragments have been previously bored, the medullary filaments of encrusting $L$. aggregatum may fill these borings so closely that the impressions may be gained, erroneously, that the encrusting alga had, itself, created the borings! Such a specimen is shown on PI. 5, fig. 2 , and this must be compared to other specimens which have been previous bored, obviously by other organisms (e.g., Pl. 5, fig. 1, where the echinoderm clast shows earlier, much finer borings and corrosion possibly by sponges and bacteria), and those which have been widely fractured, not bored at all (Pl. 4, fig. 3). Those calcareous skeletal fragments which form initial substrates for encrustation, and which are longest in contact with the L. aggregatum filaments (as well as being the most obvious source of calcium carbonate for the calcification of the growing alga), may show no boring or corrosion at all (e.g., Pl. 4, fig. 4).

As noted above, in the Introduction to this paper, the type horizon of Lithocodium aggregatum Elliott is probably Hauterivian in age, and that the species ranges from Late Jurassic (probably Oxfordian, certainbly Tithonian) to Albian, in clean micritic marine limestones of Tethys.

Radoicicinellopsis gen. nov.

Type species: Bacinella? sterni Radoičić, 1972

Diagnosis. A Codiacean genus of the subfamily Lithocodioidea (as defined above), initially encrusting but which, in later growth, becomes nodulose or subconical in shape; medullary, subdermal filaments are encrusting, oriented in various directions which are dominantly subparallel to each other and which are nearly at right-angles to the long-axis of the thallus; the cortex is (or successive cortices are) very thin and usually reduced to a thickened layer (or layers) of calcification. Remarks. Radoicicinellopsis differs from the other genera of the Lithocodioidea by the great reduction in its cortex. Biostratigraphically, it is the youngest (and last) known genus of this subfamily.

\section{Radoicicinellopsis sterni (Radoičić)}

1972 Bacinella? sterni Radoičić: 228, figs. 1 a-c.

Description. A species of the genus which has thalli of $4-6 \mathrm{~mm}$ (rarely up to $10 \mathrm{~mm}$ ) diameter and which terminally divides into two or more lobes, with densely encrusting medullary filaments, each about $0.2 \mathrm{~mm}$ in diameter.

Remarks. The type specimens were obtained by Radoičić (1972) from micritic, marine linestones of the (probably lowest) Cenomanian, exposed at Urladanas, Yugoslavia. No other records are yet known.

As the genus is monotypic, the morphocharacters of the species are not, as yet, clearly separable from those of the genus.

\section{PALAEOVENVIRONMENTAL SIGNIFICANCE}

All the records of Lithocodium aggregatum (and its synonymous references to Bacinella irregularis) which are cited in the Introduction above, and which give sufficient information for the palaeoenvironment under which the microfossils were deposited to be assessed,

\section{Explanation of Plate 4 \\ Lithocodium aggregatum Elliott}

Fig. 1. Photomicrograph $(\times 16)$, Shuaiba Formation, subsurface Abu Dhabi.

Fig. 2. Photomicrograph $(\times 40)$, Aptian, Southern Apennines, Italy.

Fig. 3. Photomicrograph $(\times 40)$, Lekhwair Formation, subsurface Abu Dhabi.

Fig. 4. Photomicrograph $(\times 16)$, Shuaiba Formation, subsurface Abu Dhabi. 

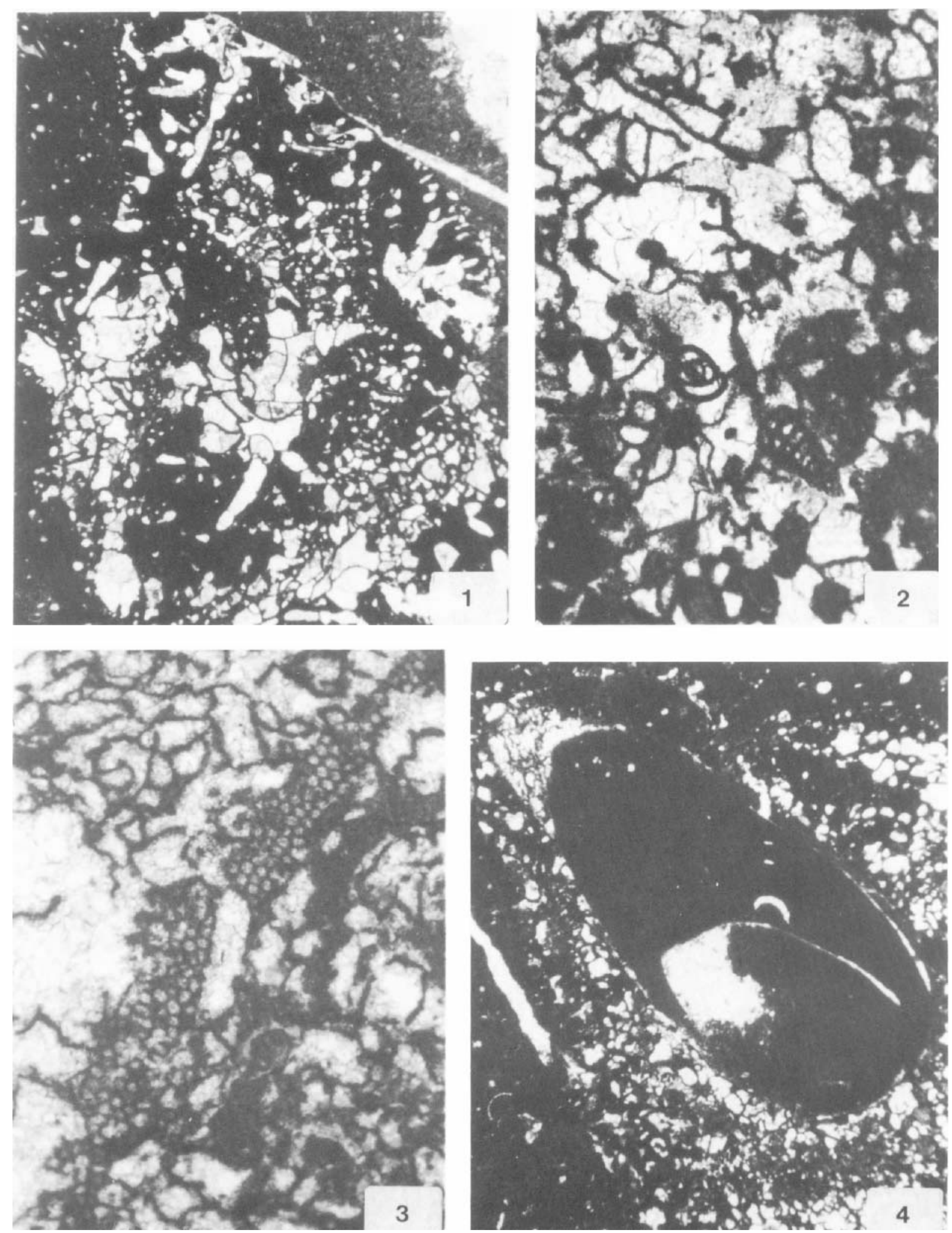
indicate that all known occurrences of this alga are from marine, micritic linestones. This, like the additional comments noted below, is in complete agreement with the observations we have made in the routine examination and record of many thousands of samples from the Mediterranean area and from the Middle East. If the limestones are sparitic, the Lithocodium specimens are found encased in micrite, and they are clearly allochthonous, having been transported and redeposited from micritic environments. These occurrences are rare; in situ specimens, in which no apparent abrasion or erosion has occurred, are found in abundance in calcareous, micritic limestone of mudstone or wackestone packing. However, Lithocodium (or any other taxa of the Lithocodioidea) has never been found by us, and its occurrence has never been substantiated, in any argillaceous rock. Specimens are known only in "clean" carbonates.

The micritic matrix in which Lithocodium occurs indicates low palaeocurrent velocities (broadly equivalent to those which would allow settlement of argillaceous mud, and therefore probably not exceeding about $10 \mathrm{~cm} / \mathrm{sec}$ speeds), and, therefore, the occurrences are unlikely to be commonly in inner-shelf palaeoenvironments, but more likely to have been in water deeper than this. This agrees with the lack of association of Lithocodium with acknowledged shallow-water Codiacea (such as Arabicodium, Boueina, etc.), but with its occurrence with deeperwater dasyclads (Acicularia, Salpingoporella. etc.), and the calcitic (possibly also dasyclad) "Hensonella" cylindrica Elliott (vel "Salpingoporella" dinarica Radoičić). This is also in agreement with our palaeodepth-estimations using associated forminifera. Other palaeoenvironmental estimates (palaeosalinity, palaeotemperature) based on associated foraminifera and other microfossils are in line with the conclusions given below. Also, the palaeogeography is that which clearly associates the known occurrences of Lithocodium with Tethys; the Lithocodioidea are not known from more boreal or austral deposits.

As a result, we estimate that the palaeoenvironment favoured by Lithocodium was that of a warm, fully marine, well oxygenated, calcium carbonate rich, mid-shelf sea (possible palaeodepths of abundant, in situ specimens ranging from $c a .15 \mathrm{~m}$ to $c a .60 \mathrm{~m} \mathrm{b.s.l.)}$. This is quite different from that which would be concluded from the opinions published by Maurin et al. (1985).

\section{RESERVOIR PROPERTIES OF LITHOCODIUM}

Lithocodium (as defined in this paper) is common or abundant at many horizons in the Early Cretaceous of the Arabian Peninsula. Simmons \& Hart (1987) and Hughes-Clarke (1988) have recorded it from the Lekhwair, Kharaib and Shuaiba Formations of Oman, whilst Alsharhan $(1985 ; 19875)$ and Alsharhan \& Nairn (1986) have described it from the Thamama Group of Abu Dhabi.

The genus is most prolific at two levels in the subsurface Thamama Group of Abu Dhabi; within the lowermost Shuaiba Formation (Aptian), termed Reservoir Zone A by ADCO for the onshore region, Reservoir Zone 1A by ADMA for the offshore region and units A and B by Alsharhan (1987), and within the lower Lekhwair formation (Valanginian - Hauterivian) at horizons termed Reservoir Zones F, G and $\mathrm{H}$ by ADCO for the onshore region, and Reservoir Zone 4 or Zakum Member by ADMA for the offshore region. As can be seen from this, prolific Lithocodium buildups seem to be associated with so called "Reservoir Zones".

Examination of these intervals reveals that Lithocodium often dominates the biofacies of the reservoir zone horizon, but is less common in the sediments surrounding the reservoir zone, termed "dense zones" by the operating companies. Lithocodium recorded from the dense zones is usually present as clearly reworked nodules or fragments. Within the reservoir zones themselves, Lithocodium forms major biostromes of layered encrustations, which are laterally continuous and may vary from a few centimetres to a metre in thickness. In thin-section they give the appearance of boundstones or packstones with abundant coalescing Lithocodium nodules.

Within the reservoir zones, only the medulla structure of the Lithocodium organism is often present (i.e. that often described as "Bacinella") (see Pl. 5, figs. 3-4). However the cortical structure may be preserved, more commonly in the Shuaiba Formation (see Pl. 1, figs. 1-3). Often the medulla structure of Lithocodium is infilled by secondary calcite spar (Pl. 1, fig. 4; Pl. 4, fig. 2). However, in samples from the subsurface of Abu Dhabi, particularly those from the reservoir zones of the Lekhwair Formation, the vesicles remained unfilled by calcite and thus develop significant intraparticle porosity (see Pl. 5, figs. 3-4). Porosities between 30 and $40 \%$ may. be developed locally, although permeabilities are variable. These porosities may be enhanced by leaching associated with the

\section{Explanation of Plate 5 \\ Lithocodium aggregatum Elliott}

Fig. 1. Photomicrograph $(\times 40)$, Lekhwair Formation, Wadi Mi'aidin, Oman Mountains.

Fig. 2. Photomicrograph $(\times 40)$, Habshan Formation, Wadi Bani Kharus, Oman Mountains.

Fig. 3. Photomicrograph $(\times 40)$, Lekhwair Formation, subsurface Abu Dhabi.

Fig. 4. Photomicrograph $(\times 16)$, Lekhwair Formation, subsurface Abu Dhabi. 

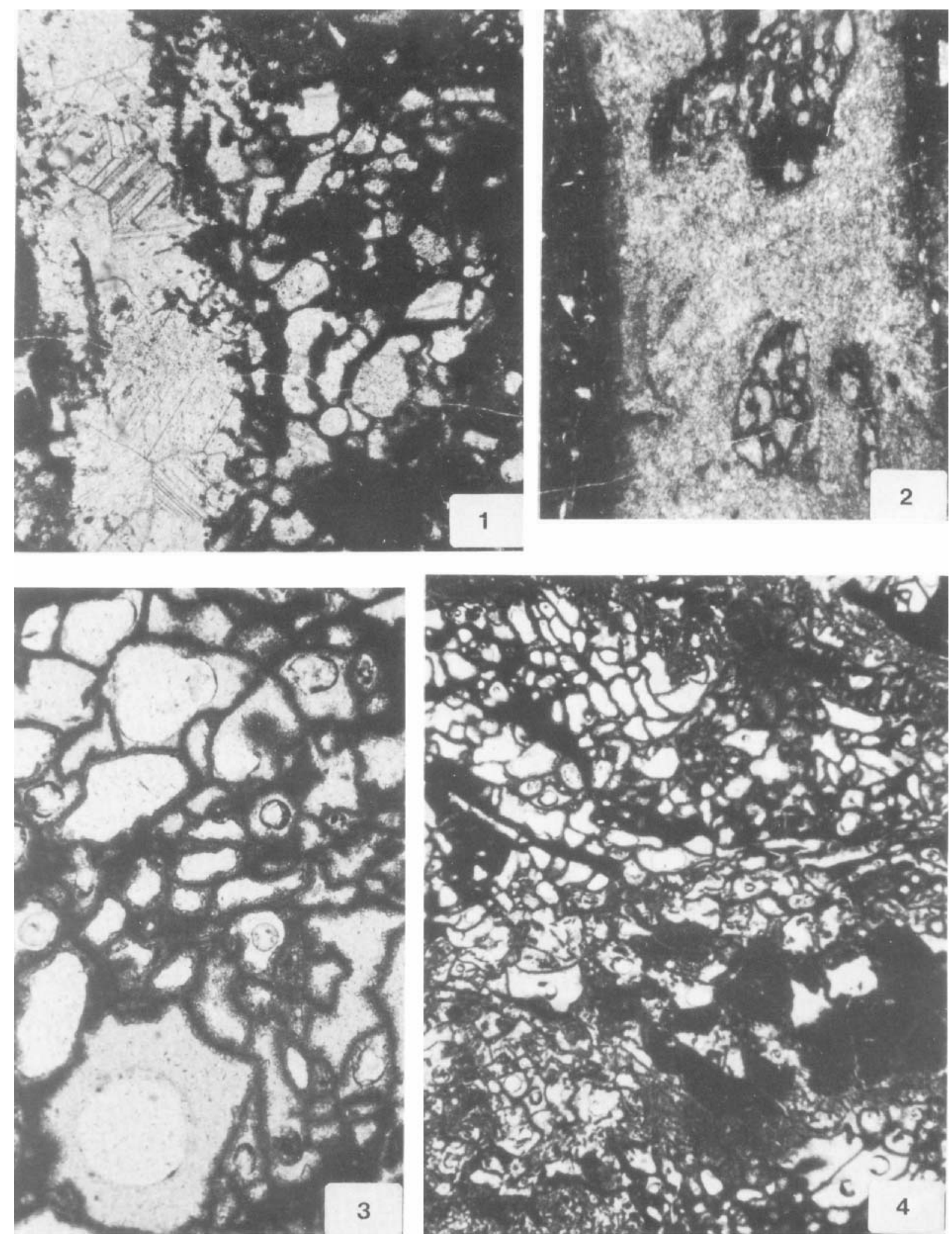
development of hiatus surfaces within the Lekhwair and Shuaiba Formation. As an example, the Zakum field of offshore Abu Dhabi produces oil from Reservoir Zone 4 (Zakum Member) of the Lekhwair formation (Beydoun, 1988) which is associated with Lithocodium accumulations. Moshier et al. (1988) have decribed the role of intraparticle porosity in Lithocodium within the Shuaiba Formation of Sharjah in the development of the giant gas and condensate reservoir of the Sajaa field.

Clearly therefore, the development of Lithocodium buildups may be beneficial for the reservoiring of large hydrocarbon accumulations. These Lithocodium buildups have an associated fauna of Lenticulina, Pseudocyclammina, Neotrocholina, echinoderm debris and occasionally small praehedbergellid planktonic forminifera. It is suggested that such buildups developed in response to moderate increases in relative water depth. Such water depth increases may themselves be eustatically controlled on carbonate platforms such as that of the Early Cretaceous of Arabia. The prediction of major Lithocodium accumulations is thus of importance in hydrocarbon exploration. This can be facilitated by the detailed study of sequential palaeoenvironmental change, with particular emphasis on water depth, within a sequence. Of course, the retention of porosity in such buildups is controlled by diagenesis which may be independent of primary depositional controls.

\section{ACKNOWLEDGEMENTS}

This paper is published with permission kindly granted by BP Research International, the Abu Dhabi Company for Onshore Oil Operation and the Abu Dhabi National Oil Company.

Manuscript received February 1989

Revised manuscript accepted September 1989

\section{REFERENCES}

Alsharhan, A. S. 1985. Depositional environment, reservoir units evolution, and hydrocarbon habitat of Shuaiba Formation, Lower Cretaceous, Abu Dhabi, United Arab Emirates. The American Association of Petroleum Geologists Bulletin, 69 (6), 899-912.

Alsharhan, A. S. 1987. Geology and reservoir characteristics of carbonate buildup in giant Bu Hasa oil field, Abu Dhabi, United Arab Emirates. The American Association of Petroleum Geologists Bulletin, 71 (10), 1304-1318.

Alsharhan, A. S. \& Nairn, A. E. M. 1986. A review of the Cretaceous formations in the Arabian Peninsula and Gulf: Part 1 - Lower Cretaceous (Thamama Group) stratigraphy and palaeogeography. Journal of Petroleum Geology, 9 (4), 365-392.

Barattolo, F. \& Pugliese, A. 1987. Il Mesozoico dell'Isola di Capri. Quaderni dell'Accademia Pontaniana, 8, 1-172, pls. I-LXVI.

Basson, P. W. \& Edgell, H. S. 1971. Calcareous algae from the Jurassic and Cretaceous of Lebanon. Micropaleontology, 17 (4), 411-433, pls. 1-7.

Bassoullet, J. P. Bernier, P., Deloffre, R., Genot, P., Jaffrezo, M., Poignant, A. F. \& Segonzac, G. 1977. Classification criteria of fossil Dasycladales. In: Flugel, E., Fossil Algae: recent results and developments. SpringerVerlag, 154-166.

Beydoun, Z. R. 1988. The Middle East: Regional Geology and Petroleum Resources. Scientific Press Ltd, 292 pp.

Borza, B. 1975. Mikroproblematika aus der oberen Trias der Westkarpaten. Geol. Zb. Slov. Akad. Vied., 26 (2), 199-236, pls. 1-8.

Bouroullec, J. \& Deloffre, R. 1968. Les Algues du Neocomien d'Aquitaine. Bull. Centre Rech. Pau-SNPA, 2 (2), 213-261, pls.1-6.

Camoin, G. \& Maurin, A-F. 1988. Roles des microorganismes (bacteries, cyanobacteries) dans la genese des "Mud Mounds". Exemples du Turonien des Jebels Bireno et Mirhila (Tunisie). C. R. Acad. Sci. Paris, 307, 401-407.

Castanier, S. 1987. Microbiogeologie: processus et modalités de la carbonatogenese bacterienne. These de Doctorate d'Etat, Universite de Nantes, 541 pp., 38 pls., 166 figs.

Cherchi, A., Gupta, V. J. \& Schroeder, R. 1984. Late Aptian calcareous algae and larger foraminifera from Khalsi, Ladakh, India. Bull. Ind. Geol. Assoc., 17 (2), 145-157, pls. 1-3.

Chiocchini, M. \& Mancinelli, A. 1977. Microbiostratigrafia del Mesozoico in facies di piattaforma carbonatica dei Monti Aurunci (Lazio meridionale). Studi Geologici Camerti, 3, 109-152, pls. I-XLVIII.

Chrischev, Chr. \& Bakalova, D. 1974. Distribution of the algae in the Emen Limestone Formation (the Lovech Urgonian Group) (in Russian). Bulgarian Academy of Sciences, Bulletin of the Geological Institute, series Stratigraphy and Lithology, 23, 65-89, pls. I-V.

Connally, T. C. \& Scott, R. W. 1985. Carbonate sediment-fill of an oceanic shelf, Lower Cretaceous, Arabian Peninsula. In: Crevello, D. \& Harris, P. M., Deep-water carbonates: buildups, turbidites, debris flows and chalks - a core workshop. SEPM Core Workshop, New Orleans, March $23-24,1985,6,266-302$.

Conrad, M. A. 1977. The Lower Cretaceous algae in the area surrounding Geneva (Switzerland): Biostratigraphy and depositional environments. Chap. 32 in: Flugel, E. (ed.), Fossil Algae, 295-300. Springer-Verlag.

Conrad, M. A., Peybernes, B. \& Radoičić, R. 1977. Salpingoporella urladansi, n. sp., une dasycladale du Crétacé inférieur d'Espagne et de Yougoslavie. Géologie Mediterranéenne, 4 (2), 73-82.

Dragastan, O. 1966. Microfaciesurile Jurasicului superior si Cretacicului infferior din muntii apuseni (M. Trascau si M. Padurea Craiului). Analele Universitatii Bucuresti (1966), $37-47$, pls. I-IV.

Dragastan, O. 1975. Upper Jurassic and Lower Cretaceous microfacies from the Bicaz Valley Basin (East Carpathians). Institut de Geologie et de Geophysique, Bucarest, Memoire, 21, 1-87, pls. 1-95.

Dragastan, O. 1985. Review of Tethyan Mesozoic algae of Romania. Chap. 10 in: Toomey, D. F. \& Nitecki M. H. (eds), Paleoalgology: contemporary research and applications, 101-161. Springer-Verlag.

Dunnington, H. V. Wetzel, R. \& Morton, D. M. 1959. Mesozoic and Palaeozoic. Lexique Stratigraphique Internationale, 3, Asie. Fasc. 10a, Iraq, 1-331.

Elliott, G. F. 1956. Further records of fossil calcareous algae 
from the Middle East. Micropaleontology, 2 (4), 327-334, pls. 1-2.

Elliott, G. F. 1957. (1956). Algues calcaires Codiacées fossiles d'Iraq, nouvelles ou peu connues. Bull. Soc. Géol. France, (6) 6, 789-795, pl. XXV.

Elliott, G. F. 1963. Problematical microfossils from the Cretaceous and Palaeocene of the Middle East. Palaeontology, 6 (2), 293-300, pls. 46-47.

Endo, R. 1961. Calcareous algae from the Jurassic Torinosu Limestone of Japan. Sci. Reports, Saitama University, ser. $B$, Endo commemorative Volume, 53-75, pls. 1-17.

Flajs, G. 1977. Skeletal structures of some calcifying algae. Chap. 25, in: Flugel, E. (ed.), Fossil Algae, 225-231. Springer-Verlag.

Flugel, E. 1982. Microfacies analysis of Limestones. SpringerVerlag, Berlin Heidelberg, 1-633, pls. 1-53.

Hughes Clarke, M. W. 1988. Stratigraphy and rock unit nomenclature in the oil-producing area of Interior Oman. Journal of Petroleum Geology, 11 (1), 5-60.

Jaffrezo, M. 1975. Les algues calcaires du Jurassique supérieur et du Crétacé inférieur des Corbiêres (2 eme partie). Revue de Micropaléontologie, 17 (1), 23-32, pls. 1-2.

Jeffrey, C. 1973. Biological Nomenclature. Edward Arnold, London.

Johnson, H. J. 1964. The Jurassic Algae. Quarterly of the Colorado School of Mines, 59 (2), 1-129, pls, 1-5.

Johnson, H. J. 1968. Lower Cretaceous algae from Texas. Professional Contributions of the Colorado School of Mines, 4, 1-71, pls. 1-12.

Johnson, H. J. 1969. A review of the Lower Cretaceous algae. Professional Contributions of the Colorado School of Mines, 6, 1-180, pls. 1-68.

Kaever, M. 1965. Mikropalaontologische untersuchungen zur Stratigraphie Afghanistans. Erdol $u$. Kohle, Erdgas, Petrochemie, 18, 638-648.

Kalantari, A. 1986. Microfacies of carbonate rocks of Iran. National Iranian Oil company, Geological Laboratories, Publ. No. 11, 1-287, pls. 1-135.

Luperto Sinni, E. 1979. I microfossili de "livello a Palorbitolina lenticularis" delle Murge baresi. Rivista Italiana di Paleontologia e Stratigrafia, 85 (2), 411-479, pls. 31-44.

Masse, J.-P. 1976. Les Calcaires Urgoniens de Provence: Valanginen - Aptien Inferieur: stratigraphie, paléontologie, les paléoenvironments et leur evolution. Thèse, Universite d'Aix-Marseille II, i-255, pls. 1-60.

Masse, J.-P. 1979. Schizophytoides du Crétacé inferieur. Caracteristiques et signification ecologique. Bull. Centre Rech. Explor. Prod. Elf-Aquitaine, 3 (2) (2nd Int. Symp. Fossil Algae), 686-703.

Maurin, A. F., Bernet-Rollande, M. C., Monty, C. L. V. \& Nazhat, S. 1985. The microbial nature of Bacinellid textures - sedimentological bearings. 9th European regional meeting of Sedimentology, Lerida, 285-287.

Mišík, M. 1979. Jurassic and Cretaceous algae (Dasycladales excepted) from the West Carpathians. Bull. Cent. Rech. Explor-Prod. Elf-Aquitaine, 3 (2), 705-712, pls. 1-2.

Moshier, S. O., Handford, C. R. Scott, R. W. \& Boutell, R. D. 1988. Giant gas accumulation in "chalky"-textured micritic limestone, Lower Cretaceous Shuaiba Formation, Eastern United Arab Emirates. SEPM Core Workshop, 12, 229-271.

Mu Xi-nan. 1986. Lower Cretaceous calcareous algae from Xainza and Baingoin, N. Xizang. Acad. Sinica, Bull. Nanjing Inst. Geol. \& Paleont., 10, 79-99, pls. I-V.
Poignant, A. 1968. Les Algues des calcaires aptiens et albiens de l'Aquitaine méridionale. Revue de Micropaléontologie, 10 (4), 271-276, pls. 1-2.

Praturlon, A. 1964. Calcareous algae from JurassicCretaceous limestone of Central Apennines (southern Latium - Abruzzi). Geol. Romana, 3, 171-202.

Radoičić, R. 1959. Nekoliko problematičnih mikrofosila iz dinarske krede. Geol. Vjesnok, 17 (1), 87-92, pls. I-III.

Radoičić, R. 1960. Microfacies du Crétacé et du Paléogene des Dinarides externes des Yougoslavie. Institut de Recherches Geologiques de la R. P. Crna Gora, (A) 4 (1), 1-172, pls. I-LXVII.

Radoičić, R. 1972. Bacinella? sterni nov. sp. (Codiacea?) from the Cenomanian of the environs of Orahovac (Metohija). Bull. Scientifique. conseil Acad. Sc. Arts RSF de Yougoslavie, (A) 17 (7-8), 228-229.

Ramalho, M. M. 1971. Contributions a l'étude micropaléontologique et stratigraphique du Jurassique superieur et du Crétacé inférieur des environs de Lisbonne (Portugal). Servicos Geologicos de Portugal, mem. 19 (n.s.), 1-212, pls. I-XXXI.

Sampo, M. 1969. Microfacies and microfossils of the Zagros area, southwestern Iran (from pre-Permian to Miocene). E. J. Brill, Leiden, 1-102, pls. 1-105.

Samuel, O., Borza, K. \& Kohler, E. 1972. Microfauna and lithostratigraphy of the Palaeogene and adjacent Cretaceous of the Middle Vah Valley (West Carpathian). Geol. Ustav. Dionýza Štúra, Bratislava, 246 pp., 180 pls.

Sartoni, S. Crescenti, U. 1962. Ricerche biostratigrafiche nel Mesozoico dell'Appennino meridionale. Giorn. Geol., (2a), 29 (1960-61), 161-304, pls. XI-LII.

Segonzac, .G. \& Marin, P. 1972. Lithocodium aggregatum Elliott et Bacinella irregularis Radoičić de l'Aptien de Teruel (Espagne); deux stades de croissance d'un seul et même organisme incertae sedis. Bulletin de Societé Géologiqué de France, (7), 14, 331-335, pl. X.

Simmons, M. D. \& Hart, M. B. 1987. The biostratigraphy and microfacies of the Early to mid-Cretaceous carbonates of Wadi Mi'aidin, central Oman mountains. In: Hart, M. B., Micropalaeontology of Carbonate Environments, chap. 10, 176-207, pls. 10.1-10.5.

Voss, E. G., Burdett, H. M., Challoner, W. G. et al. 1983. International Code of Botanical Nomenclature: adopted by the Thirteenth International Congress, Sydney, August, 1981. Bohn, Scheltema \& Holkema, Utrecht/Antwerp; Dr. W. Junk, The Hague/Boston, 1-472.

Wray, J, L. 1977. Calcareous algae. Elsevier Scientific Publishing Company, Developments in Palaeontology and Stratigraphy, 4, 1-185.

Wright, V. P. \& Wright, J. M. 1985. A stromatolite built by a Phormidium-like alga from the Lower Carboniferous of South Wales. Chap. 5 in: Toomey, D. F. Nitecki, M. H. (eds.), Paleoalgology: contemporary research and applications, 40-54. Springer-Verlag.

Zambetakis-Lekkas, A. \& Karotsieris, Z. 1986. Le Jurassique supérieur de la zone de Tripolitza dans la region de Vitina (Peloponnese central, Grece). Revue de Paléobiologie, 5 (2), 269-279, pls. I-V. 